\title{
VIEWS ON THE ISSUE OF ACCOUNTABILITY IN NON-PROFIT ORGANIZATIONS
}

\author{
HASAN BASRI \\ Faculty of Economics \\ Syiah Kuala University, Indonesia
}

A.K. SITI-NABIHA

Graduate School of Business

Universiti Sains Malaysia

\begin{abstract}
Over the past few decades, concerns have been raised about the accountability of non-profit organizations, especially on the adequacy of the current reporting and oversight mechanisms. Nonprofit organizations are now increasingly demanded to become more accountable and demonstrate that they are making a difference and delivering results. However, the issues of non-profit accountability are problematic and more complex as compared to business organisations. As such, in this paper, pertinent issues of accountability in NPO are discussed. This is done by discussing the unique nature of non-profit organisations and their conflicting demands for accountability. The paper also elaborates the complex relationship of trust and its consequences and influences on the informal and also formal forms of accountability, specifically on the use of financial reporting.
\end{abstract}

Keywords: Accounting, accountability, non-profit organization, financial reporting, trust.

\section{Introduction}

Over the last 20 years, non-profit organizations (NPOs) ${ }^{1}$ have become important providers of social services in many countries. The scope, scale and range of non-profit organizations, activities focus not only on the traditional domain of charity but include other services such as community and economic development and also refugee placement. The major sources of funding for these organisations come from membership dues, grants from governments and also private donations. Since only a small portion of a non-profit organization's support comes from sales to paying customers, financial resources of non-profit organizations come from financial contributors - individuals, foundations or governments - who are willing to pay for delivering services to beneficiaries who cannot pay for the services themselves (Mark \& Brown, 2001).

With over a million non-profit organizations in existence today, there is competition among these organizations for financial resources. With information readily available about non-profit organizations, especially through the Internet, donors are able to choose who they fund more

1 There are many terms used to describe non-profit organizations (NPOs) such as independent, third sector, voluntary, charitable, philanthropic, social, public benefit, faith-based, tax exempt, non governmental organization or civil society organization (Cameron, 2004). The term used in this article is non-profit organization. 
carefully. Consequently, non-profit organizations are now operating as serious competitors for societal resources. Leonard (2004, p.2) says that "the market place transaction for non-profits is simply the exchange of money for knowledge that the donation will likely achieve its desired goal of helping those in need". He argues that failure to satisfy the need of the donors can weaken their support. Donors may withdraw support to nonprofit organizations that are seen as unwilling to be accountable for the use of resources. This act can have a profound impact on a non-profit organization's mission and operation.

Furthermore, the financial scandals and lawsuits against non-profit organizations, which were widely reported in the media, have raised questions regarding financial management and accountability of non-profit organizations (see Eisenberg, 2005). There are perceptions that non-profit organizations have poor internal control, inadequate accounting systems, a lack of expertise and commitment to financial management and have shown lack of accountability to their stakeholders. These organisations are now expected to show more accountability by reporting the impact of their activities to their stakeholders (Herman \& Renz, 1998). The current environment is making increased accountability a fact of life in nonprofit organizations as seen can be seen as from the growing number of lawsuits against those organizations resulting from bribery or misuse of resources.

However, the issue of accountability is problematic for non-profit organisations as will be discussed in this paper especially the paradoxical role of trust and financial reporting. Hence, the purpose of this article is to review accounting and accountability issues in nonprofit organizations based on the insights from the literature. It starts with a discussion of the nature of non-profit organisations and the increasing demand and the principles of accountability in NPOs. The problematic issues of accountability then discussed are those related to increasing regulation versus self-regulation, the forms of accountability and the paradoxical role of trust and accountability.

\section{The Nature of Non-Profit Organisations}

Non-profit organizations differ from profit organizations in a number of ways. Some of the non-profit organizations carry out activities for the benefit of their members, while others carry out activities for public benefit. There are usually two types of non-profit organizations recognized by civil law; an organization of persons (individuals), typically called an "association" and an organization involving the dedication of material resources, typically called a "foundation" (Simon, 2005, p.12). A study on global civil society as quoted by the Asia Pacific Philanthropy Consortium (2006, p.1) provides the following four structural-operational features that define an organization within the non-profit organization sector. The features are:

- $\quad$ Organized, i.e. they have some structure and regularity in their operations, whether or not they are formally constituted or legally registered. More than legal or formal recognition, this qualification stresses organizational permanence and regularity, reflected in regular meetings, membership, and legitimate decisionmaking structures and procedures.

- $\quad$ Private, i.e. they are not primarily commercial in purpose and do not distribute profits to a set of directors, stockholders, or managers. While NPOs may generate a surplus from time to time, they must reinvest these resources back into the objectives of their respective organizations.

- $\quad$ Self-governing, i.e. they have their own mechanisms for internal governance. They are able to cease operation on their own authority, and are fundamentally in control of their own affairs.

- Voluntary,i.e.membership or participation in them is not legally required or otherwise compulsory.

It is argued that these four characteristics encompass both formaland informalorganisations, religious and secular, those with paid staff and those staffed entirely by volunteers and 
organizations performing expressive functions (i.e. advocacy, cultural expression, community organizing, environmental protection, human rights, religion, representation of interests, and political expression) as well as those performing service functions (i.e. provision of health, education and welfare services) (Asia Pacific Philanthropy Consortium, 2006).

Clearly, non-profit organizations exist for the benefit of the community and not for that of the management or their owners. This kind of organization is prohibited from distributing income to a set of directors, managers, individuals or any private shareholder. This is due to the absence of ownership in these organizations. Both the management and the board of the organizations are expected to operate as agents in the public's interest in ensuring the organisations' proper functioning.

\section{The Increasing Demands for Accountability}

Since all non-profit organizations operate in society on the basis of public trust to provide some type of social services, they are accountable to society for the resources received. They are now demanded to show more accountability by reporting the impact of their activities to their stakeholders (Herman \& Renz, 1998). The demand for more accountability in nonprofit organizations has come from the various stakeholders; i.e. the government, third party actors and the media (Lee, 2004; Mark \& Brown, 2001). Donors are now more discerning and they want to know where and how the funds are used (Campbell, 1998).

Naturally, donors will ask the non-profit organizations to provide information that enables them to gain assurance that their donations were administered wisely. Donors today are looking at the relative value of work of each non-profit organization they are thinking about supporting. They are looking critically at the accomplishments of the organizations, and some donors are even scrutinizing accounting documents to determine just how effective and efficient these organizations really are and the impact of the programmes they have funded (see, Campbell, 1988; Ensman, 1996).

It is argued that with more state funds being disbursed to non-profit organizations, governments will definitely demand higher levels of accountability. Third party actors, such as corruption watchdogs, have also played a significant role in the emergence and emphasis of accountability by non-profit organizations. In addition, the media has reported quite widely on the matters of accountability in non-profit organizations (see Eisenberg, 2005).

Beneficiaries press non-profit organizations to live up to their rhetoric about fostering locallydetermined development rather than imposing their own priorities. The internal staff and workers in these organisations expect them to live up to the high purposes that drew their commitment to the enterprise. Partners who nonprofit organizations have recruited in their efforts to achieve their goals (such as other non-profit organizations, government agencies, businesses) expect the non-profit organizations to live up to the promises they made in forging their partnerships. Even the recipients of their service demand some form of accountability from them. They want to know to whom the non-profit organizations are accountable and for whom the non-profit organizations speak so that they can gauge the force and legitimacy of the claims that these organizations are making against them (Mark \& Brown, 2001).

Thus, non-profit organizations have various stakeholders to whom they might owe accountability. However, NPO's accountability is problematic given that the interests of various stakeholders are sometimes not coherently aligned with one another. Consequently, the leaders of the non-profit organizations have to make choices to embrace or resist particular stakeholders and this can have a profound impact on their missions. This, of course, creates difficulty for non-profit organizations since resisting demands for accountability from 
specific stakeholders can weaken their support. Financiers may withdraw support to non-profit organizations that are seen as unwilling to be accountable for the efficient use of resources. Committed staff can stop working hard if the non-profit organization fails to embody the values and missions that brought them to the organization (Mark \& Brown, 2001).

\section{The Principles of Accountability for Non-Profit Organizations}

Accountability has been used to describe the responsibility of those who manage or control resources to others (Coy \& Pratt, 1998). The concept, in general, shows a relationship between two parties in which one party, whether it is an individual, group, company, government, or organization, is directly or indirectly accountable to another party for something, such as an action, process, output, or outcome (Kearns, 1994; Walker, 2002).

However, the precise meaning and implications of this concept are still vague. There are various conceptualizations of accountability, from a literal view that is mainly concerned with reporting activity, to encompassing activities relating to providing explanation or justification of actions. The concept has sometimes been related to the presence of a contractual relationship between two parties for particular actions. Gray et al. (1987), as quoted by Laughlin (1990, p.96) say that "accountability only occurs when contracts are in existence between principal and agent". This means that accountability occurs if contracts exist between the one who holds to account and the one who accounts.

Paul (1991) as noted by Kearns (1994, p.186) says that accountability is "holding individuals and organizations responsible for performance measured as objectively as possible". This definition means an individual or an organization being answerable to a higher authority for action taken and for handling resources they received. A broader definition of accountability is given by Romzek and Dubnick (1987) as quoted by
Kearns (1994, p. 187) "accountability involves the means by which public agencies and their workers manage the diverse expectations generated within and outside the organization". This definition contains elements not found in other previous definitions. It introduces an element of strategy wherein the management attempt to forecast diverse expectations and position their agency for proactive as well as reactive responses. The managers' role is transformed from a passive one into one of active participation in framing and articulating the standards by which they are judged.

These two definitions show that there are many important accountability relationships within an organization. In this matter, Laughlin (1990, p.95) illustrates diagrammatically the accountability relationship in Figure 1.

Figure 1 shows the relationship involving the giving and demanding that relates to some transference of resources or responsibilities from a principal to an agent with some expectations surrounding the transfer. The expectations are often complex and are either unwritten and implicit or written and explicit. Therefore, Laughlin (1990) divides this accountability relationship into contractual and communal labels. Contractual refers to a more formal context resulting in a written form of recording and defining expectation through a process that involves entering into a legally-binding agreement over standards of performance by laying them down in writing and in specific enforceable terms, whereas, communal accountability encompasses the less formal context and is less structured, expressing stakeholders' needs through consultation and seeking their involvement in the decisionmaking process (see Laughlin, 1990; Demirag et al., 2004).

However, Roberts and Scapens (1985) view accountability as a moral order that involves a system of reciprocal rights and obligation. This means that the parties are bound up not only in narrow, calculable ways, but broader than what is generally understood and must serve 


\section{Context and underlying structure of accountability relationships}

(e.g. contractual/communal, bond/link of accountability; signification, legitimation, domination)

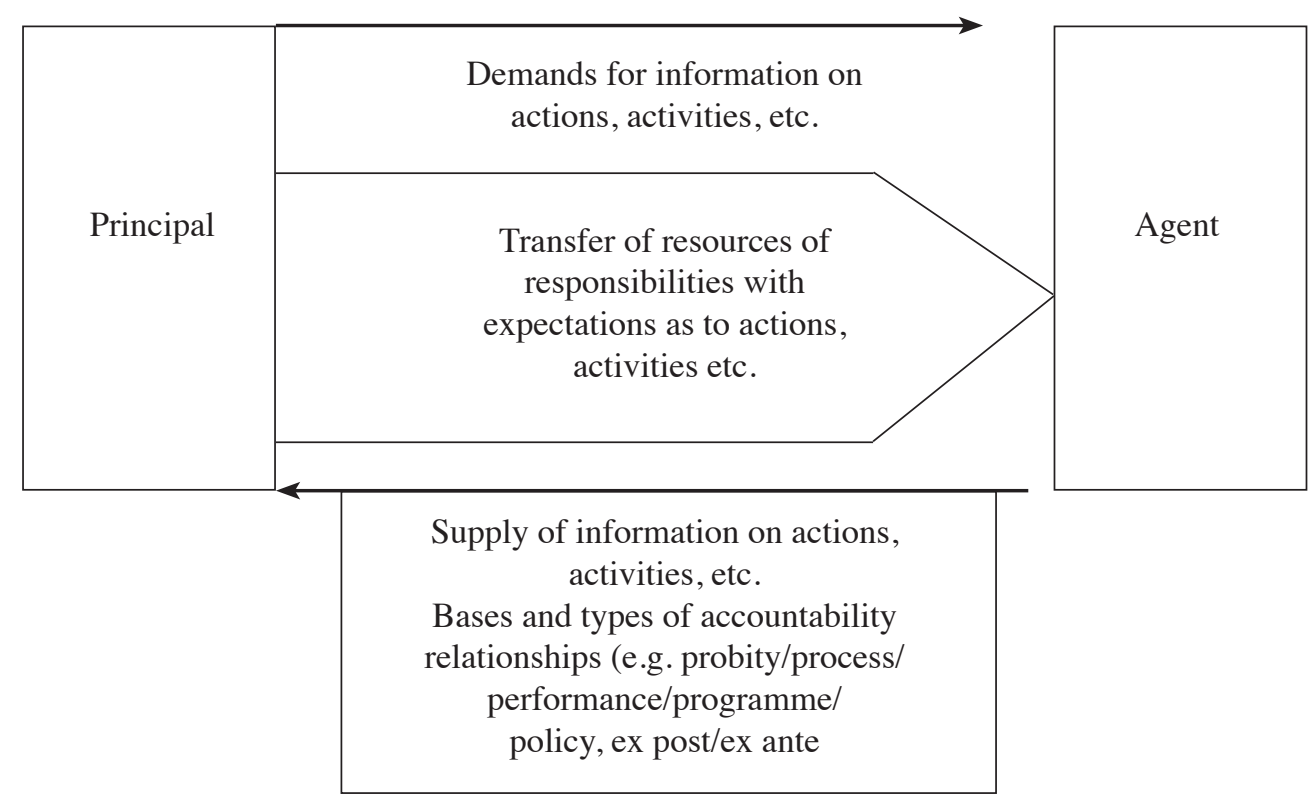

Source. Laughlin (1990, p.95).

Figure 1. Accountability relationship: A summarised picture of theoretical insight.

the moral or spiritual goals of the organization. Seen from this point of view, those in charge of economic resources must give account of their stewardship. Stewardship refers to "a person who manages another's or financial affairs; one who administers anything as an agent of another or others" (IASB, 2005, p. 2). This stewardship function has been a regular feature of organized human activities from the earliest time. Stewardship and accountability are regarded by some as similar and interchangeable (Lewis, 2006).

The principles of accountability of non-profit organizations, to a certain extent, are much different from other organizations. Since accountability is about a relationship that involves the giving and demanding of reasons for conduct in which some individuals, or organizations have certain rights to make demands over the conduct of another as well as seek reasons for the actions taken. Clearly, accountability of non-profit organizations operates under a slightly different form from those discussed in the agency theory. The agency theory, one of the popular theoretical paradigms used within the accountability literature, focuses on contractual relationship and assumption of rational and self-interested human beings in which people invest something in anticipation of receiving something.

It is difficult to apply this theory to non-profit organizations since in NPO, especially in religious organisations, there are no clearcut ownerships and principals as in profitoriented organisations, whereas the traditional understanding of accountability in organizations is linked to ownership, thus it is inappropriate 
to explain accountability relations in non-profit organizations. In addition, the agency theory is based on homo economicus and self-interest actors rationally maximizing their own personal economic gain. The model is individualistic and predicated upon the notion of an in-built conflict of interest between the owners and the managers.

Besides that, the agency model is built on the presumptions that agency cannot be trusted to act in the manner desired by the principal. It is strongly influenced by the McGregor's theory X view of people in which agents cannot be trusted to act in the manner desired by the principal (Davis and Donaldson, 1991), whereas NPO, especially a religious organisation, has put trust as a very significant element in its management activities, as the resource has to be maintained mainly on the basis of trust in the organisation rather than being exchanged in return for something tangible such as goods and services.

The stakeholder theory is seen as being broader than the agency theory. This theory rejects the idea that the organizations and enterprises exist to serve only the interests of the principals or owners. Rather, the theory is based on the idea that the organization/enterprise exists to serve many stakeholders who have interests in it or who in some way may be harmed or benefited by it (Solomon \& Solomon, 2005; Donaldson \& Preston, 1995; Elias et al., 2000).

Applying the stakeholder theory to understand accountability in non-profit organizations is problematic since it is incapable of addressing the divergent interests of the stakeholders themselves. The stakeholder theory does not provide a mediating framework enabling stakeholders to express their intentions coherently and, above all, collectively. Individual owners express their intentions in a kind of legal vacuum. It is argued that the relationship between owners and managers is replaced by a confrontation between those who have claims vis-à-vis the firm and those who do not (Learmount, 2002).

It is argued that the stakeholders theory is also associated with a rupture with patrimonial capitalism, even though, the theory has been claimed as generally being presented as an alternative to the agency theory (see, Barrett, 2001; Bonnafous-Boucher \& Pesqueux, 2006). Both the theories discussed above were developed to address accountability issues in profit-oriented organizations. Thus, the theoretical insights commonly used such as the agency theory or stakeholder theory have not been able to provide understanding on how accountability should be managed in non-profit organisations. In addition, Rudkin and Cooper (2007) also argue that applying the private sector corporate governance principles unquestioningly to the public sector and non-profit institutions and relationships leads to the simulacra of accountability rather than an authentic engagement. Hence, there is a need to develop a more suitable theoretical perspective to understand accountability in NPO since accountability in non-profit organisations is more complex as compared to profit organisations.

\section{The Problematic Accountability Issues in Npos}

\section{Governmental Control and Self-Regulation}

Much has been written about the lack of regulation for the non-profit sector as NPOs are most likely to be unregulated. The control and regulation of NPOs might be exercised by hierarchies or associations to which the organization may belong. Consequently, there have been suggestions and arguments that the non-profit sector ought to be similarly controlled as like profit organizations. It is not surprising that in almost every country with an active and growing non-profit organization and philanthropic sector, both the government and the non-profit sector itself have sought ways to strengthen the sector's transparency and accountability. As a result, the regulation for controlling these kinds of organizations has increased.

Greater transparency and accountability can be achieved through multiple, often simultaneous and overlapping means. National or sub-national (state or provincial) governments can increase direct regulatory focus and enforcement on the sector. The government of Indonesia, for 
example, has issued a law to regulate NPO specially the foundations (yayasans) since there a number of instances where the foundations have been used to illegally accumulate wealth for founders or board members (preamble to law 16/2001 as quoted by Antlōv et al., 2005).

Consequently, to restore the function of a foundation as a non-profit organization with social, religious and humanitarian goals, and to promote its accountability and transparency, the government of Indonesia issues a law which requires the foundation to show accountability from publishing the financial report in the newspapers to being audited by the public accountant. Thus, the non-profit organizations are now under pressure to professionalize transparency and governance standards in order to demonstrate that they are worthy custodians of donations and to regain control of their own agendas. Unfortunately, in practice, only a few non-profit organizations follow these rules and the enforcement is weak (Nainggolan, 2006). Thus, government regulations cannot guarantee high standards of accountability in nonprofit organizations. Other means of ensuring transparency and accountability are needed. There is a need to go beyond the law and promote higher standards for internal governance and external accountability.

One alternative is for governments to require or urge the non-profit sector to adopt self-regulatory means to strengthen accountability and transparency, or as a method for collaborating with the government on measures (such as tax exemption) that benefit the sector and society at large. Also, the non-profit sector itself can adopt self-regulating mechanisms of its own accord, either as a defensive or a proactive measure (Seidel, 2003). In spite of this, no single pattern fits or describes the variety of mechanisms for self-regulation. It is important to note that self-regulation is an emerging trend in the governance of social and economic activity both at the national and the international levels. It is estimated that NGO's self-regulatory initiatives are now in operation in over 40 countries worldwide (Lioyd, 2005). Self-regulation issues are now underway in Indonesia, but it still remains unclear whether the self-regulation mechanisms that emerged will centre on a code of ethics or conduct framework, or emphasize accreditation and/or certification, or some other structure.

\section{Forms of Accountability: Formal and Informal Mechanisms}

Gray and Bebbington (2006), argue that the issues of the size of the organisation and the formality of the accountability mechanism need to be taken into consideration in discussing the accountability of NPOs. They argue that regardless of the size of the organization, accountability will naturally occur through some combination of personal contact and the visibility of activities undertaken by the nonprofit organization. If one can, for example, visit a non-profit organization and ask about its activities, then a formal specific account is not required. They further argue that the formal form of accountability could be burdensome to many non-profit organizations, especially the smaller ones since human and financial resources are scarce and they, instead, should be channelled to the provision of services and goods.

Another issue pertaining to non-profit organizations is the existence of stakeholders who do not need formal accountability or who believe that the accountability owed to them is discharged in another manner. Andreoni (1990) as quoted by Hyndman and McDonell (2009), argue that individuals feel a "warm glow" from their act of donation that is sufficient to counteract the lack of private incentive to contribute to the public good. This individual is argued to receive all his or her satisfaction from the act of donation and none from the actual provision of the charitable services. Thus, it could be said that these types of individuals might not require a formal form of accountability from the NPOs.

Formal accountability is argued to be needed when there is lack of closeness between the stakeholders and the organisations as Rowl (1972), as quoted by Gray and Bebbington (2006, p. 335), notes that "all relationships involve 
degrees of closeness; it is only in the absence of this closeness that a formal accountability is required". Non-profit organizations, particularly, grassroot organizations are the extreme essence of closeness. Much like familial, friendship, neighbourly, and other relationships within the civil society, their very essence is one of complex, close interaction. In short, as a general rule, the greater the closeness between the organisation and its stakeholders, then, the less is the need for a formal accountability system.

In addition, it is suggested that the relationship between the organization and the stakeholders, especially their financiers, is not purely on economic terms as generating profit is not their main objective. It is a more complex relationship and reflects more complex attitudes and interaction between the organization and its various stakeholders. Often, the accountability relationship in non-profit organizations may not be, nor need to be, as formal as that between profit-oriented institutions and their shareholders. Matters such as trust, social contracts, mutuality and conscience all enter into the accountability relationship of non-profit organizations. As mentioned, formal accountability, for example, the use of the reporting system could destroy trust and have negative consequences.

\section{Trust and Financial Reporting: The Paradox}

Asphilanthropic institutions,non-profit organizations heavily depend on the public's trust since their major sources of funding come from public donations. The word trust is used to show the attitude of agents towards other agents and it also describes behaviour (Sosis, 2005). Therefore, to trust is to act on the attitude of confidence about another person's or group's reliability. A lack of trust results in reluctance to take risks in areas like saving and investment (Bekkers, 2003; Seal \& Vincent, 1997).

Given that trust is an important element of charitable giving and part of accountability relationships, it can become a key element in creating a positive attitude between the agent and the principal. Even more so for non- profit religious organizations where trust plays an essential role as the resources have to be maintained on the basis of trust rather than the exchange of something tangible such as a goods or services.

Interestingly, it is argued that the utilization of a monitoring mechanism undertaken through formal accounting systems could destroy trust (Seal \& Vincent, 1997, p.407). The level of trust of the stakeholders to the organisation influences the nature of the accountability mechanisms. A low level of trust means the need for a contractual form of account. The expectation of the principal or stakeholders can be expressed in more specific terms. When there is a high level of trust, the contractual form of accountability, if given, could destroy trust as Seal and Vincent (1997, p. 407) argue "there is no need for contract... the introduction of formal mechanisms such as contracts may displace human linkages and therefore breakdown trust". It is likely that the presence of high trust will lead to the use of a communal form of accountability. Nevertheless, it is argued that efficient contracting cannot come about other than in an environment of trust.

In spite of this, financial reporting is still seen as one of the ways of showing accountability and building the stakeholders' trust. Stakeholders' access to available financial information means that the donors know about how their donations are used in carrying out their activities. Thus, an organisation that discloses more information about management and finances will gain more support and confidence from the public (Kuan et al., 2003). Accounting for receipts and expenditure of funds is the major aim of financial reporting and this can improve the stakeholders' trust. Without access to financial information, as a product of a formal accounting, donors will not be able to make optimal decisions. Ijiri (1975), as quoted by Watkins (2007), notes that accountability provides the basis of accounting. Nearly every transaction is likely to affect some stakeholders' interest. Therefore, accountability relationships and the need for financial reporting arise with every transaction. Clearly, there is a reciprocal relationship between accounting and accountability. 
It is argued that through financial reports the stakeholders can oversee and monitor the activities performed by the organizations. The stakeholders, including donors, clients, the government and creditors can analyse financial reports to assess the performance of the organizations. This assessment will influence the stakeholders' decision that will have financial implications for the organizations. This relationship, between the provider of information and the users of it, is seen as accountability relationship. Those who are held responsible for accounting are bound to give an account of their actions, and are responsible for the outcome of those actions (see Keating \& Frumkin, 2003, \& Devi, et al., 2004, p. 457).

Keating and Frumkin (2003, p.5) illustrate diagrammatically in Figure 2, the financial reporting systems that include two key groups: the organization as a provider of financial reporting and the stakeholders as the users of it.

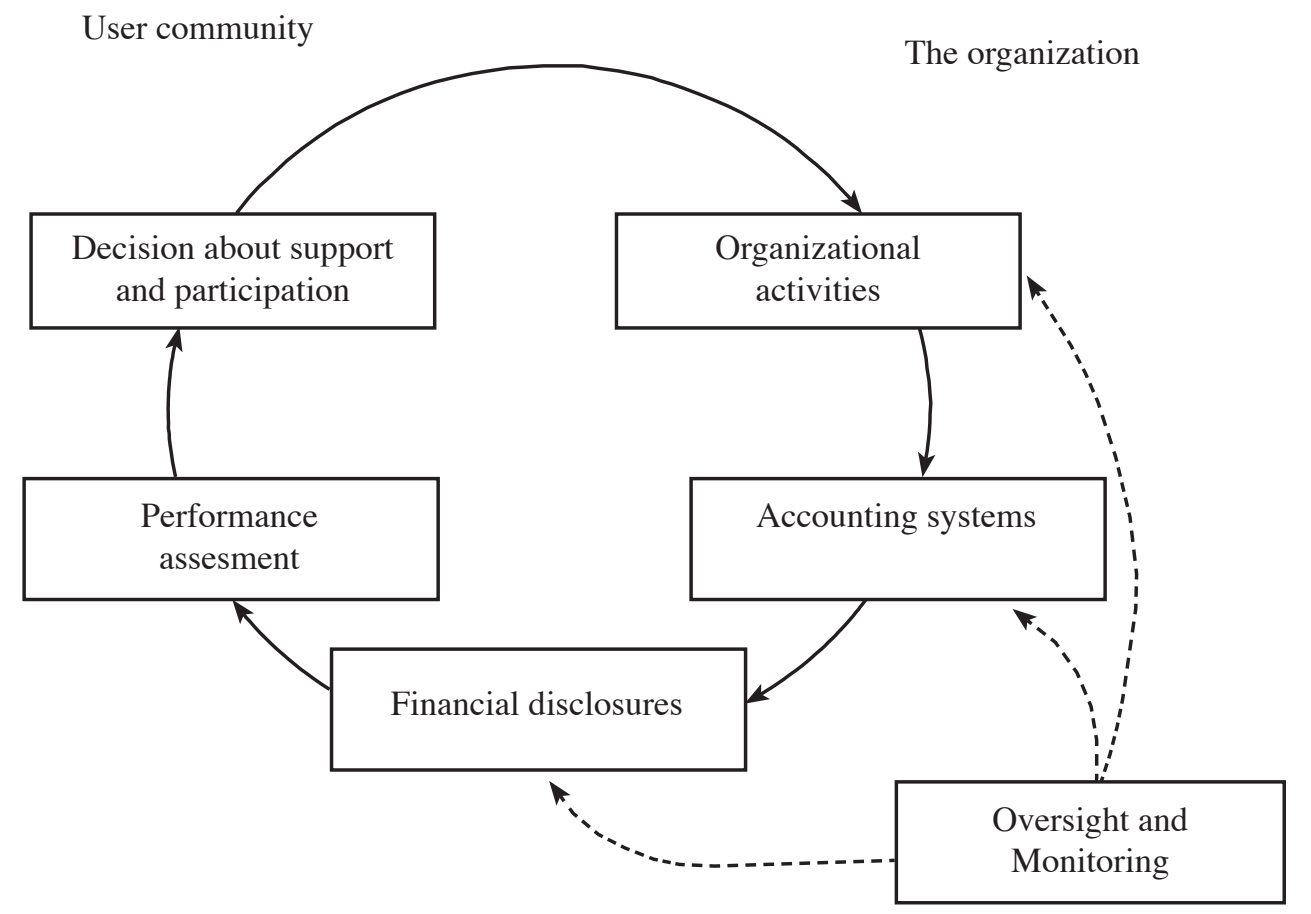

Source: Keating and Frumkin (2003,p. 4)

Figure 2. The financial reporting system.

As can be seen from the above model in Figure 2 , two key groups are involved in the financial reporting systems: the organization and the stakeholders. The organization relies on the accounting system to provide information and supplies it to its stakeholders through the financial reporting systems. The stakeholders, in turn, create a demand for information for decision-making purposes. Hence, it could be argued that the future success of a non-profit organization depends not only on the quality of its social activities, but also on improving the way it measures its work and communicates these results to its stakeholders. Accordingly, 
accounting and formal accountability has become a key component of long-term trust in any relationship. Thus, financial reporting is important in helping stakeholders to analyse and develop a performance assessment of the organization. It supplies quantitative information for economic decision-making. Thus, financial reporting has long been used as the main accountability tool by various NPOs, regardless of their objectives and missions.

Thus, should formal accountability, in the form of financial reporting be given due to the conflicting arguments that it builts trust or in certain cases destroyed trust? To solve this conundrum, the real task is to determine the empirical circumstance under which formal accounting and contracting processes are compatible with the development of trust and compel the philanthropic organizations to follow a set of a best practices and ethical behaviours to build accountability, transparency and trust (Seal and Vincent, 1997).

\section{Conclusion}

- Various issues pertaining to accountability of non-profit organizations have been discussed in this paper. The discussions include the nature of non-profit organizations and a number of meanings attached to the term-accountabilityand the various important aspects of non-profit accountability such as, trust, competition in the non-profit sector, regulations for non-profit organizations and the role of financial reporting in enhancing accountability in non-profit organizations.

It is evident that non-profit organizations differ from profit organizations in a number of ways. They carry out activities for public benefit and are not primarily commercial in purpose. These kinds of organizations are built around varied and complex missions with varied and complex constituents. Thus, non-profit organizations have multiple stakeholders or constituents who are likely to use different criteria to evaluate their effectiveness. As philanthropic institutions, their operations strongly depend on public trust since their major sources of funding come from public donations. Therefore, they must be accountable to society for the resources received.

Over the past few decades, concerns have been raised about the accountability of this sector, especially regarding the adequacy of current reporting and oversight mechanisms. The public want to be assured that their donations to these types of organization are being properly managed. The importance of holding NPOs more accountable for the proper handling of the resources entrusted to them is well documented in the management and accounting literature.

\section{References}

Asia Pacific Philanthropy Consortium. (2006). Non-profit sector accounting: Issues and recommendations (pp. 1-36). Retrieved from www.asianphilanthropy. org

Barrett, M. (2001). A stakeholder approach to responsiveness and accountability in non-profit organizations. Social Policy Journal of New Zealand, 17, 36-51.

Bekkers, R. (2003). Trust, accreditation, and philanthropy in the Netherlands. Nonprofit and Voluntary Sector Quarterly, 32(4), 596-615.

Berger, J. (2003). Religious non-governmental organizations: An exploratory analysis. International Society for Third-Sector Research and the Johns Hopkins University, 1-23.

Bonnafous-Boucher, M., Pesqueux. (2006). Stakeholder theory as a weak theory of civil society. Retrieved from http:// www.advancia.fr/uploads/_advancial publications/Paper_MBB_Stakeholder theory.pdf

Booth, P. (1993). Accounting in churches: A research framework and agenda. Accounting, Auditing \& Accountability, 6(4), 37-67.

Cameron, H. (2004). The non-profit phenomenon: Internet resources for nonprofit organizations. Retrived from http:// www.infotoday.com/researcher/feb04/ cameron.shtml. 
Campbell, B. (1998). Donors want to know where the \$ goes. Fund Rising Management, 29(5), 40-42.

Coy, D., \& Pratt, M. (1998). An insight into accountability and politics in universities: A case study. Accounting, Auditing and Accountability Journal, 11(5), 540-561.

Demirag, I., Dubnick, M., \& Igbal M. K. (2004). A framework for examining accountability and value for money in the UK's private finance initiative. UK: Queen's University.

Devi, S. S., Hooper, K., \& Davey, H. (2004). Accounting theory and practice: A Malaysian perspective. Pearson Malaysia: Prentice Hall.

Davis, J. H., \& Donalson, L. (1991). Stewardship theory or agency theory: CEO governance and shareholder returns. Australian Journal of Management, 16(1), 49-65.

Donaldson, T., \& Preston, L. E. (1995). The stakeholder theory of the corporation: Concepts, evidence. The Academy of Management Review, Briarcliff Manor, 20(1), 65-92.

Eisenberg, Pablo. (2005). Looking ahead: What is the future for the non-profit world? The International Journal of Not-for-Profit Law, 8(1), 1-7.

Ensman, R. (1996). New approach to accountability. Fund Rising Management, 26(11), 58.

Elias, A. A., Cavana, R. Y., \& Jackson, L. S. (2000). Linking stakeholder literature and system dynamic: Opportunities for research. Proceedings of International Conference on System Thinking in Management, Geelong, Australia, pp. 174-179.

Gray, R., Owen, D., \& Adams, C. (1996). Accounting and accountability. Europe: Prentice Hall.

Gray, R., \& Bebbington, J. (2006). NGOs, civil society and accountability: Making the people accountable to capital. Accounting, Auditing and Accountability Journal, 19(3), 319-348.

Hall, P. D. (2002). Accountability in faithbased organizations and the future of charitable choice. Houser Centre for
Non-Profit Organizations (1-16). John F. Kenndy School of Government, Harvard University.

Herman, R. D., \& Renz, D. O. (1998). What is not-for-profit organization effectiveness? The Not-for-Profit CEO Monthly Letter, Focus Missions, special issue.

IASB. (2005). Conceptual framework Objectives of financial reporting: Stewardship and accountability (Agenda Paper 7), IASB Meeting London, pp. 1-10.

Keating, E. K., \& Frumkin, P. (2003). Reengineering non-profit financial accountability: Toward a more reliable foundation for regulation. Public Administration Review, 63(1), 3-15.

Kearns, K. P. (1994). The strategic management of accountability in non-profit organizations: An analytical frame-work. Public Administration Review, 54(2), 185-192.

Laughlin, R. C. (1990). A model of financial accountability and the church of England. Financial Accountability and Management, 6(2), 93-114.

Learmount, S. (2002). Theorizing corporate governance: New organizational alternatives. ESRC Centre for Business Research. University of Cambridge Working Paper, 237, pp. 1-28.

Lee, J. (2004). NGO accountability: Rights and responsibilities. Programme on NGOs and Civil Society. CASIN, Genewa, Switzerland.

Lewis, M. K. (2001). Islam and accounting, feature article. Accounting Forum, 25(2), 103-127.

Lewis, M. K. (2006). Accountability and Islam. Fourth International Conference on Accounting and Finance in Transition, Adelaide.

Lioyd, R. (2005). The role of NGO self-regulation in increasing stakeholder accountability. One World Trust. Retrieved from http:// www.oneworldtrust.org Charity No 210180.

Mark, H. M., \& Brown, L. D. (2001). Accountability, strategy, and international non-governmental organizations. The Hauser Center for Nonprofit Organizations. The Kennedy School of Government, Harvard University. 
Rahim, A., \& Goddard, A. (2003). Accountability verstehen: A study of accounting in state religious councils in Malaysia. Discussion Paper in Accounting and Finance. International Islamic University Malaysia.

Roberts, J., \& Scapens, R. (1985). Accounting systems and system of accountabilityunderstanding accounting practices in their organizational contexts. Accounting Organization and Society, 10(4), 443456.

Rudkin, K., \& Cooper, K. (2007). Accumulation and scarcity: An accountability safari. Working Papers Series. University of Wollongong, School of Accounting and Finance.

Seal, W., \& Vincent, P.-J. (1997). Accounting and trust in the enabling of long-term relations. Accounting, Auditing, and Accountability Journal, 10(3), 406-437.

Seidel, J. V. (1998). Qualitative data analysis. Retrieved from http;// www. qualisresearch.com
Sidel, M. (2003). Trend in non-profit selfregulation in the Asia Pacific region: Initial data on initiatives, experiments and models in seventeen countries. University of Iowa College of Law, Iowa City, Iowa.

Simon, K. W. (2005). Reform of China's laws for NPOs, a discussion of issues related to Shiye Danvei reform. Centre for International Social Development, Catholic University of America.

Solomon, J., \& Solomon, A. (2005). Corporate governance and accountability. John Wiley \& Sons.

Sosis, R. (2005). Does religion promote trust? The role of signaling, reputation and punishment. Interdisciplinary Journal of Research on Religion, 1(7), 1-30.

Walker, P. (2002). Understanding accountability: Theoretical models and their implications for social service organizations. Social Policy and Administration, 36(1), 62-75.

Watkins, A. L. (2007). An accountability view of accounting, guidance for accounting practice. The CPA Journal, 77(2), 6-9. 